\title{
Marketed Surplus and Demand for Improved Groundnut Varieties: Empirical Evidence From Smallholders in Central and Northern Malawi
}

Admire Katunga ( $\square$ katungaadmire@gmail.com )

Chitedze Agricultural Research Services https://orcid.org/0000-0003-2025-0632

Edilegnaw Wale Zegeye

University of the Free State

Gerald Ortmann

University of Kwazulu-Natal School of Agricultural

\section{Research}

Keywords: Endogenous switching probit, High yielding crops, Marketed surplus, Smallholders.

Posted Date: June 2nd, 2021

DOI: https://doi.org/10.21203/rs.3.rs-547356/v1

License: (c) (i) This work is licensed under a Creative Commons Attribution 4.0 International License.

Read Full License 
2 smallholders in central and northern Malawi

3

5

6

7

8

(9)

1 *Admire Katunga, Department of Agricultural Research Services, Chitedze Agricultural Research Services, P.O. Box 158, Lilongwe, Malawi.+265 996765015: Email: katungaadmire@gmail.com

${ }^{2}$ Edilegnaw Wale Zegeye, Department of Agricultural Economics, Faculty of Natural and Agricultural Sciences, University of the Free State, P.O. Box 339, Bloemfontein 9300, Republic of South Africa. Mobile: +27 620244330, Email: ZegeyeEW@ufs.ac.za

${ }^{3}$ Gerald Ortmann, University of Kwazulu-Natal School of Agricultural, Earth and Environmental Sciences Discipline of Agricultural Economics P Bag X01 Scottsville 3209, Pietermaritzburg, South Africa, Phone +27 33260 5410, Fax +27 33260 5970, Email: ortmann@ ukzn.ac.za

* Corresponding author

\section{Abstract}

The quest to increase marketed surplus prompts farmers to demand high-yielding crop varieties. Understanding the farmers' challenges to increase marketed surplus would contribute to policy intervention measures that increase crop yields. Using an Endogenous Switching Probit regression (ESP) model, the study investigated the effect of marketed surplus on-demand for improved groundnut varieties and determined the factors that affect marketed surplus. The study used data collected from 416 farm households in some selected districts of central and northern Malawi. The ESP estimates showed that marketed surplus had a positive impact on the demand for improved groundnut varieties. The demand for improved groundnut varieties increased by $40 \%$ among smallholders with a marketed surplus. Conversely, the demand for improved groundnut varieties 
among farmers with no marketed surplus declined by $14 \%$. Other findings suggest that increased crop productivity, smallholders' engagement in off-farm economic activities, and enhanced access to market information are critical in increasing marketed surplus. Therefore, policy intervention measures that encounter the farmers' challenges in the output market are critical for the increased marketed surplus to enhance the demand for improved varieties.

Key Words: Endogenous switching probit; High yielding crops; Marketed surplus; Smallholders.

\section{6}

37

38

\section{INTRODUCTION}

Low crop yields that farmers realize are, among others, attributed to the use of low-yielding conventional crop varieties (Minde et al., 2008). For example, FAOSTAT (2021) reports that between 1980 and 2000, Malawi recorded negative national average annual growth rates in both production and productivity (yield per hectare) of groundnuts. During that period, most farmers cultivated low-yielding conventional groundnut varieties (Minde et al., 2008). However, the situation improved between 2001 and 2010 when average growth rates in production, productivity, and seed supply of improved groundnut variety increased to record highs of $21 \%, 12 \%$, and $3 \%$, respectively (FAOSTAT, 2021). Thus, in addition to expanding the cultivated land area for groundnuts, high-yielding improved varieties injected into the production system played a role (Minde et al., 2008; Siambi et al., 2015). At the farm level, the increase in production means enough harvest for household consumption and sale. Therefore, the increase in the production of marketable surplus is critical for enhanced commercialized crop production. Besides, commercialized crop production also entails increased demand for highly productive agricultural technologies, including improved crop varieties (Pingali and Rosegrant, 1995; Pingali, 1997). 
52 The demand for particular crop varieties among producers is commensurate with their production

53 orientation. For example, farmers that produce food crops solely for consumption choose varieties

54 that address basic survival needs (Wale and Chianu, 2015). Such farmers would cultivate low-

55 yielding crop varieties since the production is purely for subsistence. Conversely, farmers that

56 consider farming as their primary source of income and are inclined to increase marketed surplus

57 demand high yielding improved varieties (Wale and Chianu, 2015; Wale and Holm-Mueller,

58 2017). Marketed surplus, which describes the actual quantities of produce sold (Govereh et al.,

59 1999; Strasberg et al., 1999; Chirwa, 2009), triggers farmers to participate in the market as sellers

60 of commodities (Lemi, 2020). Thus farmers with a high propensity to participate in the market

61 would demand high productive farm inputs (Alene et al., 2000), such as improved crop varieties.

62

63 The preceding discussion associates the demand for improved varieties with the marketed surplus

64 of crops. However, empirical evidence of the impact of marketed surplus on-demand for improved

65 crop technologies among smallholders in sub-Saharan African (SSA) remains sparse. Nonetheless,

66 the empirical literature is awash with studies on the positive impact of adopting improved crop

67 varieties on various welfare indicators. These studies include Manda et al. (2018), Manda et al.

68 (2016) and Khonje et al. (2015) in eastern Zambia, Shiferaw et al. (2014) in Ethiopia, Bezu et al.

69 (2014) in Malawi, Asfaw et al. (2012) in Tanzania and Ethiopia and Kassie et al. (2011) in Uganda.

70 All these studies considered outcomes of interventions (welfare effects) as continuous variables.

71 Inquiry on such continuous variables requires that farm households recall actual events that

72 happened months or some years in the past. Therefore, it becomes a challenge for smallholders

73 who rarely keep records of their daily production undertakings. The consequence is that in some 
cases, one may understate or overstate the situation leading to bias or measurement of error (Beegle

75 et al., 2011)

77 Because of the above, the current study closes the gap in empirical literature by investigating the impact of marketed surplus on-demand for improved varieties. The study employs an Endogenous

79 Switching Probit (ESP) econometric technique. In the ESP model, both selection and outcome 80 variables are binaries (Aakvik et al., 2000). The ESP estimates the treatment's actual effects on 81 the outcome response variable by controlling for selection biases of treatment decision 82 (Wooldridge, 2010). Application of the ESP, in this paper, addresses the following questions:

2. What are the factors that affect smallholders' marketed surplus of groundnuts?

The study adds to existing empirical studies, other factors that affect marketed surplus. The study 87 also contributes to the policy formulation of strategies that would address the challenges smallholders encounter to increase marketed surplus. The rest of the paper proceeds as follows. Section 2 presents a brief overview of groundnuts in Malawi. The empirical model estimation procedure is presented in section 3. Section 4 presents the definition of variables and data sources used in the study. The study results and discussion are reported in section 5 , followed by the conclusion and policy recommendations in the final section.

\subsection{Overview of Smallholder Groundnut Subsector in Malawi}

In Malawi, groundnut (Arachis hypogea) is one of the legume crops widely cultivated by 96 smallholders, mainly women (Simtowe et al., 2010; Msere et al., 2015; Tsusaka et al., 2016a). In

97 this case, a policy promotion of its production has implications on women's economic 
empowerment. Further, the Malawi Government promotes its increased production for its potential contribution to sustainable food security and increased agricultural incomes (Malawi-Government, 2011; Gourichon and Mkomba, 2014; Malawi-Government, 2016). Farmers cultivate both conventional and improved varieties. Popular conventional and improved varieties are Chalimbana and CG7, respectively (Chiyembekeza et al., 1998; Goyder and Mang'anya, 2009). The latter is a relatively higher-yielding variety than the former, with a potential yield superiority of $60 \%$ (Derlagen and Phiri, 2012). The Agro-processing industry demand Chalimbana for confectionary making, while CG7 is suitable for processing cooking oil (Chiyembekeza et al., 1998; Tsusaka et al., 2016b). Similarly, farm households prefer the former for home consumption while cultivating the latter for the market.

Like in any other developing country, smallholders in Malawi own an average of fewer than 0.5 hectares of land to cultivate a diverse number of food and cash crops (Malawi-Government, 2005), thus resulting in low levels of total crop production. In addition, the use of rudimentary agricultural technologies (Mwangi and Kariuki, 2015) contributes to low crop production among the smallholders. Because of the low yields, the smallholders are also less likely to increase their market participation intensity, affecting the crop subsector's commercialization (Collier and Dercon, 2014a). Low crop yields, coupled with limited commercialisation, are linked to smallholder farm households with high poverty incidences (Diao et al., 2010). Groundnut productivity among the smallholders is also relatively low, with smallholders' yields below the potential levels (Siambi et al., 2015). One of the underlying reasons for low productivity is that the smallholder continues to utilize low productive crop technologies, such as conventional groundnut varieties (Simtowe et al., 2010b). With such low yields, it is not surprising to see a low 
121 commercialization drive among the smallholder subsectors. The smallholders consume much of

122 the groundnuts they produce with little to offer to the market (Derlagen and Phiri, 2012).

123

1242 METHODS

$125 \quad 2.1 \quad$ Empirical Model Estimation Procedure

126 The study adopts an Endogenous Switching Probit (ESP) model to investigate the impact of

127 marketed surplus on farmers' demand for improved varieties of groundnuts in central and northern

128 Malawi. The ESP controls for endogeneity biases in the treatment effect framework (Lokshin and

129 Sajaia, 2011). Other econometric models that control endogeneity biases include Heckman's two-

130 step, double hurdle, endogenous switch regression, and conditional mixed process (Cragg, 1971;

131 Heckman 1979; Roodman, 2009). The difference between the ESP and the other models is that the

132 former is appropriate in modelling decisions where both the selection and outcome response 133 variables are binaries (Carrasco, 2001; Lokshin and Glinskaya, 2009; Lokshin and Sajaia, 2011).

134 For the other models, only the treatment response variable is binary, while the outcome is 135 continuous.

137 Let $M P_{i}$ (treatment variable) denote a binary taking 1 for smallholders who are inclined to increase 138 a marketed surplus, 0 otherwise. Similarly, $D I_{i}$ (outcome variable), also a binary, with 1 indicating 139 smallholders that demand for improved varieties and 0 otherwise. The selection and outcome 140 equations are, in turn, specified in equations (1), (2), and (3).

$$
M P_{i}=1 \text { if } \gamma Z_{i}+\mu_{i}>0 ; M P_{i}=0 \text { if } \gamma Z_{i}+\mu_{i} \leq 0
$$

$$
D I_{1 i}^{*}=\alpha_{1} X_{1 i}+\varepsilon_{1 i} ; D I_{1 i}=I\left(D I_{1 i}^{*}>0\right) ; D I_{0 i}^{*}=\alpha_{0} X_{0 i}+\varepsilon_{0 i}
$$




$$
D I_{i}=D I_{0 i} \text { if } M P_{i}=0
$$

146 Where $D I_{1 i}^{*}$ and $D I_{0 i}^{*}$ are the latent variables that determine the binary outcomes $D I_{1}$ and $D I_{0}, X_{1}$

147 and $X_{0}$ are vectors of weakly exogenous variables, $Z$ is a vector of variables that determine a switch

148 between and $\alpha_{0} \gamma$ are vectors of parameters; and $\mu_{i}, \varepsilon_{1 i}$ and $\varepsilon_{0 i}$ are the error terms. The observed

149 demand for improved varieties $D I_{i}$ is a dichotomous realization of $D I_{i}^{*}$ if the farmer has no 150 marketed surplus.

151

152 The assumption made in this type of model is that farmers' decision to demand improved varieties 153 is endogenous to having a marketed surplus. Some unobservable characteristics that influence the 154 probability that a farmer would have marketed surplus could also influence improved varieties' 155 demand. Neglecting this endogeneity in the unobservable covariates in both treatment and outcome 156 regression equations is likely to yield biased estimates of the impact of marketed surplus on157 demand for improved varieties. The use of instrumental variables in the selection equation 158 overcomes biased estimates' problems (Makate et al., 2016). A falsification test is conducted on 159 the outcome equation's probit regression to identify the correct instrumental variables. The chi160 squared's insignificance $p$-value indicates that the variables are the suitable instruments used in 161 the selection equation but not in the outcome.

163 A post estimation is conducted to find parameters that measure the treatment variables' effects on 164 the desired outcome (Heckman and Vytlacil, 2000). In this study, marketed surplus of groundnuts 165 is the treatment or selection variable, while the demand for improved varieties of groundnuts is the 
outcome variable. The most relevant post estimation parameters are the average treatment effect on the treated (ATET), which estimates the effect of marketed surplus on-demand for improved varieties for smallholders with the marketed surplus. The effect of farmers with no marketed surplus on-demand for improved varieties estimates the average treatment effect on untreated (ATU). Other parameters are the average treatment effect (ATE) and the average marginal treatment effect (MTE). The former is the average effect of marketed surplus for groundnuts ondemand for improved varieties for smallholders selected at random from the population. The latter describes the treatment effect for smallholders that are indifferent as to whether to increase marketed surplus or not. Lokshin and Sajaia (2011) and Aakvik et al. (2000) provide more details of the ESP model.

Estimating the parameters that indicate the impact of marketed surplus on-demand for improved varieties proceeds with determining factors that affect marketed surplus. Denote the marketed surplus as $M P_{i}=Q_{i}-X_{i}^{\prime}$, where $M P_{i}$ is a marketed surplus, $Q_{i}$ is the total household output, $X_{i}$ is a vector of household consumption that includes part of the harvest used as seed and given away as gifts. In autarky, nothing is traded, $M P=0 \forall_{i} \in$ not traded. However, when the farmer sells part of the harvest, then $M P_{i}>0 \forall_{i} \in$ is traded. Then the selection equation with its determinants is given as,

$$
\begin{aligned}
M P_{i=} \alpha_{0} & +\alpha_{1} \text { AGERESS }+\alpha_{2} \text { AGERESSQD }+\alpha_{3} \text { PCWORK }+\alpha_{4} \text { OXCART } \\
& +\alpha_{5} \text { PGNUTHA }+\alpha_{6} \text { YIELD }+\alpha_{7} \text { SEEDCOST }+\alpha_{8} \text { OUTPUTMARK } \\
& +\alpha_{9} \text { MOBP }+\alpha_{10} \text { SEEDLOAN }+\alpha_{11} \text { EXT }+\alpha_{12} \text { SEEDMULT } \\
& +\alpha_{13} \text { PRDBUYERS }+\alpha_{14} \text { RODST }+\alpha_{15} \text { DISTMARK }+\varepsilon_{i}
\end{aligned}
$$


where all the variables are as defined in Table 1 and $\varepsilon_{i}$ are the unobservable covariate.

189

190

191

192

193

194

195

196

197

198

199

200

201

202

203

204

205

206

207

208

209

210

211

\subsection{Data Sources and Definition of Variables}

Table 1 defines the variables used in the study. Dependent variables comprised a selection variable, marketed surplus $(M P)$, and an outcome variable, demand for improved varieties $(D I)$. In the former case, farm households indicated, in local measurements, the quantity of the crop harvest that they sold in 2015/16. According to Patnaik (1975), this is the marketed surplus. The marketed surplus was then converted as the proportion of the total harvest. Because it is the produce sold, such proportion indicates the household's commercialization index (Govereh et al., 1999; Strasberg et al., 1999; Chirwa, 2009). According to Strasberg et al. (1999) and Govereh et al. (1999), a commercialization index of close to 0 means that crop production is purely for subsistence. The index close to 1 implies that the household produces for the market. In this study, all index values equal to and above 0.5 were considered to be marketed surplus. Commercialization indices below 0.5 were considered to be non marketed surplus. A binary variable was generated for marketed surplus with 1 and 0 otherwise. For the outcome variable, farmers who replaced conventional varieties with improved ones in 2016/17 were considered to have expressed demand for the latter. Consequently, the variable was coded 1 for the demand, 0 otherwise.

Explanatory variables hypothesized to explain a marketed surplus of groundnuts were identified based on past empirical work (Alene et al., 2008; Zanello, 2012; Adenuga et al., 2013; Burke et al., 2015). These variables were categorized as socio-economic characteristics, market accessrelated factors, institution factors, and market transaction cost factors 


\subsubsection{Socio-economic characteristics}

Farmers' age (AGERESS and AGERESSQD) is expected to have a nonlinear relationship with a marketed surplus. Young farmers are more inclined to increase marketed surplus than older ones (Gebremedhin and Jaleta, 2010; Mirie and Zemedu, 2018; Das, 2020). Involvement in piece work jobs (PCWORK), known as 'ganyu' in Malawi, is an income diversification strategy for farm households (Ellis, 1998). However, Whiteside (2000) pointed out that ganyu is counterproductive to household productivity as it competes with its labour demand. Because ganyu contributes to low household crop productivity, the marketed surplus is also expected to decline. The oxcart is the most used means of transporting inputs and produce to and from the market in some of SSA countries' rural areas. Therefore, it is expected that farm household that own oxcarts (OXCART) to increase marketed surplus.

Households' productive assets, such as the proportion of land allocated for the cultivation of crops (PGNUTHA), are expected to increase production, hence marketed surplus (Goyal and Berg, 2004; Faris et al., 2018). An increase in yield per hectare of land (YIELD) increases the marketed surplus (Wambua et al., 2019). The seed for modern varieties, especially groundnuts, are costly. Their supply is low because private traders consider the enterprise to have narrow profit margins (Minde et al., 2008; Siambi et al., 2015). Therefore, their demand falls with an increase in cost (SEEDCOST). The decline in the demand for certified seed reduces crop productivity, negatively affecting marketed surplus.

\subsubsection{Market access related factors}

Farmers with access to output market information (OUTPUTMARK) are more likely to intensify their participation in the market (Aslam et al., 2019), hence increase marketed surplus due to the prospects of finding buyers that offer better prices. 
238 Table 1: Definition of variables used in the study

\begin{tabular}{|c|c|c|}
\hline Dependent Variables & Measurement & Expected Sign \\
\hline Demand for Improved & 1=Smallholder demand for improved groundnut & \\
\hline Varieties (DI) & varieties & \\
\hline Marketed Surplus (MP) & 1=Smallholder with marketed surplus & \\
\hline \multicolumn{3}{|l|}{ Independent Variables } \\
\hline \multicolumn{3}{|c|}{ Socio-economic Characteristics } \\
\hline AGERESS & Age of the farmer in years & Positive \\
\hline AGERESSQD & Age squared of the farmers in years & Negative \\
\hline PCWORK & $1=$ Household involved in piece work jobs & Negative \\
\hline OXCART & $1=$ Household owns an oxcart & Positive \\
\hline PGNUTHA & The proportion of land planted with groundnuts & Positive \\
\hline YIELD & The yield of groundnuts in kg ha-1 & Positive \\
\hline \multirow[t]{3}{*}{ SEEDCOST } & Cost of seed per hectare (Malawi Kwacha; & Negative \\
\hline & MK730=1US\$) & \\
\hline & Market Access & \\
\hline OUTPUTMARK & $1=$ Smallholder' access to market information & Positive \\
\hline MOBP & $1=$ Household possess a mobile phone & Positive \\
\hline \multicolumn{3}{|l|}{ Institutional Factors } \\
\hline SEEDLOAN & $1=$ Household has access to seed loan & Positive \\
\hline EXTS & $1=$ Household has access to extension services & Positive \\
\hline SEEDMULT & $\begin{array}{l}1=\text { Household is located in areas with seed } \\
\text { multiplication activities }\end{array}$ & Positive \\
\hline PRDBUYERS & $\begin{array}{l}1=\text { Smallholder sold produce to mobile grain } \\
\text { buyers }\end{array}$ & Negative \\
\hline \multicolumn{3}{|c|}{ Transaction Costs Factors } \\
\hline RODST & $\begin{array}{l}1=\text { Households resides in areas with poor road } \\
\text { network }\end{array}$ & Negative \\
\hline DISTMARKT & $\begin{array}{l}\text { Time, in minutes, taken to reach the nearest } \\
\text { market }\end{array}$ & Negative \\
\hline
\end{tabular}

239 Source: Farm household survey (2017); n=Total sample size 
240 In addition, farmers who possess mobile phones (MOBP) can link with many prospective buyers

241 of produce (Aker, 2010; Aker, 2011; Zanello, 2012), leading to an increased marketed surplus.

242

243

244

245

246

247

248

249

250

251

252

253

254

255

256

257

258

259

260

261

262

263

\subsubsection{Institutional factors}

Mobile grain buyers (PRDBUYERS) are the informal market sources to which smallholders sell produce. However, crop producers claim that such grain buyers cheat them by using unstandardized weighing scales and offer lower prices (Pokhrel and Thapa, 2007). As a result, groundnut producers, whose main buyers are mobile traders, are less inclined to increase marketed surplus. On the other hand, agricultural extension agents (EXT) enable farm households to access market information for their produce. Therefore, contacts with extension agents would positively affect marketed surplus (Bahta and Bauer, 2012.; Faris et al., 2018).

Most smallholder farmers cannot afford to purchase improved seed varieties because they are expensive. To ease their access, some farmer organizations offer seed loans (SEEDLOAN) to them. Access to the seed loans would increase production through farmers' access to viable seed, hence would increase marketed surplus (Mmbando et al., 2015).

\subsubsection{Market transaction cost factors}

Poor status of rural roads (RODST) increases transportation costs to bring produce to markets. Therefore, not only would producers' transportation costs increase with poor road conditions, but also buyers of produce. As a consequence, the marketed surplus would decline (Fentie et al., 2017). Similarly, smallholders who take a long time to reach markets (DISTMARKT) are also less likely to decrease marketed surplus (Fentie et al., 2017) due to increased transportation costs. 


\section{EMPIRICAL RESULTS AND DISCUSSION}

\section{7}

268

269

270

271

272

273

274

275

276

277 The average land allocated to the cultivation of groundnuts was 0.33 ha, while the average yield

278 realized was about $890 \mathrm{~kg} \mathrm{ha}^{-1}$. Allocation of 0.33 ha of land to groundnut cultivation against a

279 mean landholding size of 1.5 ha indicates that smallholders perceive the crop as a potential cash

280 crop. Above $50 \%$ of farmers possessed mobile phones and had access to market information from

281 different sources. On average, the farmers take one and a half hours to travel to the nearest output

282 market, and $14 \%$ of them reside in areas with poor road conditions.

284 The poor road conditions and the long time that smallholders take to reach markets imply that they

285 incur more transportation costs, negatively affecting marketed surplus. A small percentage of the

286 farmers (18\%) had access to seed loans, while most of them (84\%) had access to extension

287 services. The small percentage of farmers who had access to seed loans shows that most of them

288 still face challenges to access better quality seeds. The percentage of smallholders that were aware 
289 of improved groundnut varieties was 63\%. Most smallholders (97\%) sold their produce to mobile

290 grain buyers.

291

292 Table 2: Socio-economic characteristics of smallholder groundnut producers $(n=416)$

\begin{tabular}{|c|c|c|c|c|}
\hline Dependent Variables & Mean & Std. Dev. & Min & Max \\
\hline Demand for Improved Varieties & 0.411 & 0.493 & 0 & 1 \\
\hline Marketed Surplus & 0.738 & 0.440 & 0 & 1 \\
\hline \multicolumn{5}{|l|}{ Independent Variables } \\
\hline \multicolumn{5}{|c|}{ Socio-economic Characteristics } \\
\hline AGERES & 45.957 & 12.869 & 20 & 82 \\
\hline AGERESSQD & 2277.231 & 1243.837 & 400 & 6724 \\
\hline PCWORK & 0.433 & 0.496 & 0 & 1 \\
\hline OXCART & 0.306 & 0.251 & 0 & 1 \\
\hline PGNUTHA & 0.333 & 0.323 & 0.025 & 6.075 \\
\hline YIELD & 892.429 & 537.049 & 49.180 & 2926.829 \\
\hline SEEDCOST & 8.042 & 4.591 & -4.605 & 11.711 \\
\hline \multicolumn{5}{|c|}{ Market Access } \\
\hline OUTPUTMAKINFOR & 0.596 & 0.491 & 0 & 1 \\
\hline MOBP & 0.548 & 0.498 & 0 & 1 \\
\hline \multicolumn{5}{|c|}{ Institutional Factors } \\
\hline SEEDLOAN & 0.180 & 0.385 & 0 & 1 \\
\hline EXTS & 0.841 & 0.366 & 0 & 1 \\
\hline SEEDMULT & 0.632 & 0.483 & 0 & 1 \\
\hline PRDBUYERS & 0.974 & 0.160 & 0 & 1 \\
\hline \multicolumn{5}{|c|}{ Transaction Costs Factors } \\
\hline RODST & 0.142 & 0.349 & 0 & 1 \\
\hline DISTMARKT & 1.498 & 3.754 & -4.605 & 5.991 \\
\hline
\end{tabular}

293 Source: Farm household survey data (2017); n=Total sample size

294 


\subsection{Farm Household Utilization of Groundnut Harvested in 2015/16}

Table 3 presents farm household utilization of groundnut they harvested in the 2015/16 growing season. The mean productivity (yield per hectare) of the groundnut was about $890 \mathrm{~kg} \mathrm{ha}^{-1}$. The yield is slightly above what was previously reported (Simtowe et al., 2010; Siambi et al., 2015). Farm households' average commercialization index, which is the marketed surplus, was 0.58 . The mean consumption and seed recycling indices were at 0.24 and 0.18 , respectively. As indicated, the household commercialization index (HCI), the marketed surplus, was higher than what previous empirical literature observed (Gourichon and Mkomba, 2014). The change in the farmers' production orientation explains the increase in the marketed surplus.

Table 3: Utilization of groundnut produced by smallholders in the study areas $(n=416)$

\begin{tabular}{lcrrr}
\hline Quantity of Groundnut & Min. & \multicolumn{1}{l}{ Max. } & \multicolumn{1}{l}{ Mean } & \multicolumn{1}{c}{ Std. Dev. } \\
\hline Total production $(\mathrm{kgs})$ & 15.00 & 2500.00 & 402.820 & 376.077 \\
\hline Productivity $\left(\mathrm{kg} \mathrm{ha}^{-1}\right)$ & 49.18 & 2926.83 & 892.429 & 537.049 \\
Marketed Surplus & 0.00 & 1.00 & 0.580 & 0.270 \\
Seed Index & 0.00 & 1.00 & 0.180 & 0.156 \\
Consumption Index & 0.00 & 1.00 & 0.240 & 0.216 \\
\hline
\end{tabular}

Source: Farm household survey (2017); n= Total sample size

Over a decade ago, groundnut producers in Malawi consumed more of the harvest than what they sold (Diop et al., 2004; Gourichon and Mkomba, 2014). During the same period, low-yielding varieties dominated the production system (Minde et al., 2008). The increase in marketed surplus and household commercial index for groundnuts in Tables 2 and 3 suggests that the smallholders cultivate relatively more improved varieties than they previously did. 


\begin{tabular}{llllll}
\hline Variable & Obs. & Mean & Std. Dev. & Min & Max \\
\hline ATET & 307 & 0.407 & 0.185 & -0.980 & 0.783 \\
ATU & 108 & -0.141 & 0.292 & -0.904 & 0.332 \\
ATE & 416 & 0.264 & 0.195 & -0.980 & 0.759 \\
MTE & 100 & 0.295 & 0.043 & 0.224 & 0.372
\end{tabular}

Source: Output from data analysis

332 The positive impact of marketed surplus on-demand for improved varieties is a manifestation that the farmers who are inclined to participate in the market demand relatively more high-yielding

334 varieties than those who do not participate. The current study's findings are consistent with Wale 335 
336 demand high yielding improved crop varieties. Similarly, Derlagen and Phiri (2012) indicated that

337 improved varieties of groundnuts are relatively more superior in yield to conventional ones. Thus,

338 for increased marketable surplus and the desire to intensify market participation, crop producers

339 would indeed demand improved crop varieties.

\subsection{Estimates of Endogenous Switching Probit Regression}

342

343

344

345

346

347

348

349

350

351

352

353

354

355

356

357

358

359

360

361

362

The ESP model's estimated results (Table 5) showed that the Wald chi-squared was highly significant, suggesting the joint explanatory power of independent variables on the selection's response variables and outcome equations. The $\rho$ estimates indicate that the errors' correlation is significantly different from zero at about a 5\% level, indicating the unobserved covariates' dependence in the two equations. Therefore, unobservable covariates in the equations for the smallholders' marketed surplus and demand for improved varieties are associated, hence estimating the equations jointly.

\subsection{Determinants of Marketed Surplus for Smallholder Groundnut Producers}

In the treatment effect framework, only determinants of the response variable of the selection equation are relevant. Therefore, Table 5 reports the factors that determine the marketed surplus, which is the treatment response variable, of this study. The results in the Table show that socioeconomics and market access factors had positive effects on marketed surplus.

\subsubsection{Socio-economic factors}

The proportion of land allocated to groundnut positively affected marketed surplus at a $1 \%$ significance level. 
363 Table 5: Estimates of determinants of marketed surplus for groundnuts $(n=416)$

\begin{tabular}{|c|c|c|c|c|}
\hline Variables & Coef. & Std. Err & Z Score & $P>Z$ \\
\hline CONSTANT & -1.846 & 1.086 & -1.700 & 0.089 \\
\hline \multicolumn{5}{|c|}{ Socio-economic factors } \\
\hline AGERESP & 0.019 & 0.041 & 0.460 & 0.643 \\
\hline AGERESPSQD & 0.000 & 0.000 & -0.650 & 0.514 \\
\hline PGNUTHA & $2.105 * * *$ & 0.584 & 3.610 & 0.000 \\
\hline YIELD & $0.001 * * *$ & 0.000 & 6.800 & 0.000 \\
\hline PCWORK & $0.353 * *$ & 0.155 & 2.270 & 0.023 \\
\hline OXCART & 0.383 & 0.374 & 1.020 & 0.306 \\
\hline SEEDCOST & 0.015 & 0.017 & 0.890 & 0.376 \\
\hline \multicolumn{5}{|c|}{ Market access factors } \\
\hline OUTPUTMAKTINFOR & $0.242 *$ & 0.136 & 1.780 & 0.075 \\
\hline MOBP & 0.165 & 0.158 & 1.050 & 0.294 \\
\hline DISTRICT_DUMM & -0.101 & 0.261 & -0.390 & 0.697 \\
\hline DISTMARKT & 0.012 & 0.021 & 0.580 & 0.561 \\
\hline \multicolumn{5}{|c|}{ Institution factors } \\
\hline PRDBUYERS & 0.081 & 0.397 & 0.200 & 0.838 \\
\hline SEEDLOAN & -0.273 & 0.202 & -1.350 & 0.177 \\
\hline EXTS & -0.037 & 0.212 & -0.170 & 0.862 \\
\hline SEEDMULT & 0.152 & 0.195 & 0.780 & 0.435 \\
\hline \multicolumn{2}{|c|}{ Number of Observations: 416} & \multicolumn{2}{|c|}{ Wald Chi2(15) $=80.5$} & \\
\hline \multicolumn{2}{|c|}{ Log likelihood =-434.765 } & \multicolumn{2}{|c|}{ Prob $>$ Chi $2=0.000$} & \\
\hline \multicolumn{2}{|l|}{ /athrho1 } & \multicolumn{2}{|c|}{$0.422(0.977)$} & \\
\hline \multicolumn{2}{|l|}{ /athrho0 } & \multicolumn{2}{|c|}{$-13.043(506.626)$} & \\
\hline \multicolumn{2}{|l|}{ Rho1 } & \multicolumn{2}{|c|}{$0.399(0.821)$} & \\
\hline \multicolumn{2}{|c|}{ Rho0 } & \multicolumn{2}{|c|}{$-1.000(9.50 \mathrm{e}-09)$} & \\
\hline \multicolumn{5}{|c|}{ Likelihood Ratio test of Independent equations rho $1=\mathrm{rho} 0=0$} \\
\hline \multicolumn{4}{|c|}{$\begin{array}{ll}\text { Chi2 }(2)=5.69 & \text { Prob }>\text { Chi2 }=0.058 \\
*, * *, * * *: \text { Significance at } 10 \%, 5 \%, 1 \% & \end{array}$} & \\
\hline
\end{tabular}

364 Source: Farm household survey data (2017), n=Total sample size

365 The positive effect of this coefficient estimate on marketed surplus suggests that as land for crop 366 cultivation increases, crop production also increases. Similary, FAOSTAT (2021) reports that 367 when the land area for cultivation of groundnuts increased, the crop's production increased by $21 \%$ 
368 between 2001 and 2010. Further, Goyal and Berg (2004), Chinn (1976), and Belayneh et al. (2018)

369 attest to the positive effect of cultivated land area on marketed surplus. To this end, Bardhan (1970)

370 observed that the increase in production also entails an increase in marketed surplus. With

371 increased production, producers would have sufficient for consumption as well as for sale.

372 However, the expansion of land for the cultivation of crops is not feasible at the current moment

373 with the increase in the country's population (Malawi-Government, 2018). In this case, farmers

374 may reduce land for some crops and reallocate to those with high market demand at a particular

375 point in time.

376

377 Further results show that the coefficient estimates of the yield of groundnuts positively affected

378 marketed surplus at a 1\% significance level. In Malawi, groundnut is an essential income source

379 (Minde et al., 2008; Simtowe et al., 2010; Makoka, 2012). In this case, an increase in marketed

380 surplus is a prerequisite for the farm households to increase the quantity of commodities they

381 would sell (Bardhan, 1970; Barrett, 2008; Belayneh et al., 2018; Lemi, 2020). To increase yield,

382 hence marketed surplus, requires that farm households use high productive farm inputs or practice

383 good crop husbandry (Chinn, 1976; Baba et al., 2010). The use of improved varieties and reduction

384 in pre-harvest losses, timely crop harvest could contribute to yield increase and marketed surplus. 385

386 In other results, smallholders' involvement in piece work jobs was positive and affected marketed 387 surplus at a 5\% significance level. However, the current study's findings on the positive effects of 388 piece work jobs and the increased marketed surplus are unexpected. By undertaking the piece 389 work, farm households experience reduced labour availability at their farms (Whiteside, 2000), 390 thus negatively affecting production and reducing the marketed surplus. Furthermore, farm 
391 households use the income from piece work jobs to meet other home necessities (Ralitza et al., 392 2010). Therefore, such income cannot be available to purchase productive farm inputs. Further, 393 households' wages from piecework jobs are always low (Ralitza et al., 2010), making such income 394 inadequate for investment on the farm. However, the current study's finding suggests that farm 395 households opted to be paid in kind (farm inputs), which increased crop yields. Also, the 396 households might have undertaken the piecework jobs during off-peak periods of labour demand 397 in their fields which never affected them.

\subsubsection{Market access factors}

400

Access to market information positively affected marketed surplus at a $10 \%$ significance level. In Malawi, farmers access market information from different sources, namely, extension agents, farmer organizations, fellow farmers, and produce buyers. The expectation is that farmers with 404 access to various information sources would increase marketed surplus due to reduced market transaction costs. Without access to market information, farm households would incur search costs

406 in finding the market of their produce through personal visits to the markets. Similarly, Omiti et 407 al. (2009) and Bukul and Washo (2018) suggest that access to market information increased market 408 participation intensity, increasing the marketed surplus among the smallholders in Kenya's peri409 urban areas and Ethiopia respectively.

\section{CONCLUSION AND POLICY IMPLICATIONS}

414 surplus on-demand for improved varieties of groundnuts among smallholder groundnut producers 415 in Malawi. The ESP model was preferred to other econometrics models, such as the endogenous 
416 switching regression because both the selection and outcome equations had response variables

417 which were binaries. The study also determined the factors that affect marketed surplus. The study

418 results indicated that despite groundnut production and productivity not changing much for over a

419 decade, the average commercialization index for groundnuts was higher than previously reported.

420 The ESP estimates results showed that increased marketed surplus positively impacted the demand

421 for improved varieties among the smallholders. In addition, the demand for improved varieties of

422 groundnuts increased among farmers that were inclined to increase marketed surplus. The positive

423 impact of marketed surplus on-demand for improved varieties suggests that farmers who want to

424 increase the intensity to participate in the market put more value on high-yielding traits of

425 groundnuts than any other varietal attributes.

426

427 Conversely, the demand for improved varieties among the farmers that had no marketed surplus

428 declined. The reduction in demand for improved varieties among smallholders with no marketed

429 surplus suggests that production for this category of farmers was purely for subsistence. Other

430 findings suggest that increased crop and land productivity, smallholders' engagement in off-farm

431 economic activities, and enhanced access to market information are critical for the marketed

432 surplus to trigger demand for improved groundnut varieties. The study's findings have policy

433 implications on the output market's performance as a catalyst to increase the demand for improved

434 varieties. Thus, policy interventions should not only focus on the input market but also on the

435 challenges farmers encounter in the output market that financially capacitates them to meet the 436 cost of improved seeds. 


\section{DECLARATIONS}

440

441

442

443

Availability of Data and Materials

The data supporting the findings for this study can be obtained upon request from the

444 corresponding author.

445

446 Competing Interests

447 The authors declare that they have no competing interests.

448

449

Funding

450

451

This research received funding from the World Bank through the Agricultural Productivity

452 Program for Southern Africa (APPSA, Malawi) under the program's capacity building component,

453 which was hosted by the Ministry of Agriculture and Food Security, coordinated by the

454 Department of Agricultural Research Services.

455

456

Author's Contributions

457 AK: Conceptualized the idea, handled the data analysis and the discussion of the results and 458 approved the final manuscript.

459

460 EWZ: Provided guidance from the research's conceptualization, data collection, analysis, and 461 discussion of the result and read and approved the final manuscript.

462

463 GFO: Proofread the manuscript to ensure its quality and approved the final manuscript.

464

465 Author's information 
466 Admire Katunga has a Ph.D. in Agricultural Economics. He works for the Department of

467 Agricultural Research Services, Chitedze Agricultural Research Station, Malawi, as an 468 Agricultural Research Economist. His research interests are Agricultural Development 469 Economics, Cost-Benefit Analysis of Development Projects/Programs/Policies, and Impact 470 Assessment/Technology Adoption.

471

472 Edilegnaw Wale Zegeye is a Professor in the Department of Agricultural Economics, Faculty of 473 Natural and Agricultural Sciences, University of the Free State, Republic of South Africa. His 474 research interests are The Economics of Water Use in Smallholder Agriculture, Natural Resources 475 Economics, Agro biodiversity Economics, Agricultural Development Economics, Cost-Benefit 476 Analysis of Development Projects/Programs/Policies, and Impact Assessment/Technology 477 Adoption.

478

479 Gerald Ortmann is a Professor Emeritus at the University of KwaZulu-Natal, School of 480 Agricultural, Earth and Environmental Sciences, Discipline of Agricultural Economics, Republic 481 of South Africa. His research interests are in Farm and Financial Management, Agricultural Policy 482 (including Institutional Economics) and Development Economics.

483

484

485

\section{Acknowledgments}

The corresponding author conveys his gratitude to the enumerators and the farmers who collected 487 data and provided the questionnaire responses.

\section{Ethics Approval and Consent to Participate}

491 The study received ethical clearance from the hosting institution (University of KwaZulu Natal) 492 and consent from the participating farmers.

\section{Consent for Publication}


Not Applicable

\section{References}

498

Aakvik, A, Heckman, JJ and Vytlacil, EJ 2000. Treatment effects for discrete outcomes when responses to treatment vary among observationally identical persons: An application to Norwegian vocational rehabilitation programs Technical Working Paper Series 262. Massachusetts, USA: National Bureau of Economic Research Cambridge.

Adenuga, A, Fakayode, S and Adewole, R. 2013. Marketing efficiency and determinants of marketable surplus in vegetable production in Kwara State, Nigeria. Paper presented at the $4^{\text {th }}$ International Conference of the African Association of Agricultural Economists, Hammamet, Tunisia,

Alene, AD, Manyong, V, Omanya, G, Mignouna, H, Bokanga, M and Odhiambo, G 2008. Smallholder market participation under transactions costs: Maize supply and fertilizer demand in Kenya. Food Policy 33 (4): 318-328.

Alene , AD, Poonyth, D and Hassan, RM 2000. Determinants of adoption and intensity of use of improved maize varieties in the central highlands of Ethiopia: A Tobit analysis. Agrekon 39 (4).

Aslam, M, Ayub, MA, Yasin, M, Iqbal, Q and Atta, B 2019. Dynamics of marketed surplus of major vegetables in Multan, Pakistan.

Baba, S, Wani, M, Wani, S and Yousuf, S 2010. Marketed surplus and price spread of vegetables in Kashmir valley. Agricultural Economics Research Review 23: 115-128.

Bahta, S and Bauer, S 2012. Policy options for improving market participation and sales of smallholder crop producers: A case study of the Free State Province of South Africa. African Journal of Agricultural Research 7 (24): 3525-3533.

Bardhan, K 1970. Price and output response of marketed surplus of foodgrains: A cross-sectional study of some North Indian villages. American Journal of Agricultural Economics 52 (1): $51-61$.

Barrett, CB 2008. Smallholder market participation: concepts and evidence from eastern and southern Africa. Food Policy 33 (4): 299-317. 
Belayneh, B, Tefera, T and Lemma, T 2018. Determinants of common bean (Phaseolus Vulagris L.) marketed surplus among smallholder farmers in Humbo and Damot Gale Woredas, Southern Ethiopia. Journal of Food Industry 2 (1): 20-29.

Bukul, BB and Washo, DH 2018. Determinants of head cabbage marketed surplus among smallholder farmers in Kofale and Kore Districts, Oromia Region, Ethiopia. Developing Country Studies 8 (8).

Burke, WJ, Myers, RJ and Jayne, TS 2015. A triple-hurdle model of production and market participation in Kenya's dairy market. American Journal of Agricultural Economics 97 (4): 1227-1246.

Carrasco, R 2001. Binary choice with binary endogenous regressors in panel data: Estimating the effect of fertility on female labor participation. Journal of Business and Economic Statistics 19 (4): 385-394.

Chinn, DL 1976. The marketed surplus of a subsistence crop: Paddy Rice in Taiwan. American Journal of Agricultural Economics 58 (3): 583-587.

Chirwa, EW 2009. Determinants of marketing channels among smallholder maize farmers in Malawi. Working Paper 3. Zomba, Malawi: University of Malawi.

Chiyembekeza, A, Subrahmanyam, P, Kisyombe, C and Nyirenda, N 1998. Groundnut: A package of recommendations for production in Malawi. Lilongwe, Malawi: Ministry of Agriculture and Irrigation.

Cragg, JG 1971. Some statistical models for limited dependent variables with application to the demand for durable goods. Econometrica 39 (5): 829-844.

Das, KB 2020. Determinants of Niger Seed Marketed Surplus Among Small Farm Households: The Case of Wama Hagalo Districts of East Wollega, Ethiopia. Journal of Economics and sustainable development 11 (9).

Derlagen, C and Phiri, H. 2012. Analysis of incentives and disincentives for groundnuts in Malawi. Rome, Italy Food and Agriculture Organization.

Diop, N, Beghin, J and Sewadeh, M 2004. Groundnut policies, global trade dynamics, and the impact of trade liberalization. World Bank Policy Research Working Paper. Washington, DC, USA: World Bank

Ellis, F 1998. Household strategies and rural livelihood diversification. The journal of development studies 35 (1): 1-38. 
FAOSTAT 2021. Online agricultural statistics In: FAO (ed.). Rome, Italy.

Faris, A, Shumeta, Z and Muche, M 2018. Determinants of marketed surplus of potato producers in Dedo District of Jimma Zone, Ethiopia. World Journal of Agricultural Sciences 14 (2): $74-80$.

Fentie, MB, Goshu, D and Tegegne, B 2017. Determinants of potato marketed surplus among smallholder farmers in Banja District, Awi Zone of Amhara Region, Ethiopia. International journal of agricultural Economics 2 (4): 129-134.

Gebremedhin, B and Jaleta, M. 2010. Commercialization of smallholders: Is market participation enough. Paper presented at the Joint 3rd African Association of Agricultural Economists (AAAE) and 48th Agricultural Economists Association of South Africa (AEASA), Cape Town, South Africa,

Gourichon, H and Mkomba, F. 2014. Analysis of price incentives for groundnuts in Malawi, Rome, Italy: Food and Agriculture Organization

Govereh, J, Jayne, T and Nyoro, J. 1999. Smallholder commercialization, interlinked markets and food crop productivity: Cross-country evidence in eastern and southern Africa. USA: Michigan State University.

Goyal, S and Berg, E 2004. An analysis of marketed surplus response of cereals in Haryana State of India. Agribusiness: An International Journal 20 (3): 253-268.

Goyder, H and Mang'anya, M. 2009. Legumes platform baseline study. Malawi: Research Into Use Program.

Heckman , JJ 1979. Sample selection bias as a specification error. Econometrica, 47 (1): 153-161.

Heckman, JJ and Vytlacil, EJ 2000. The relationship between treatment parameters within a latent variable framework. Economics Letters 66 (1): 33-39.

Lemi, GD 2020. Analysis of Determinants of Sesame Marketed Surplus. The Case of Gida Ayana Districts, Western Oromia, Ethiopia. Journal of Marketing and Consumer Research 70 (24).

Lokshin, M and Glinskaya, E 2009. The effect of male migration on employment patterns of women in Nepal. The World Bank Economic Review 23 (3): 481-507.

Lokshin, M and Sajaia, Z 2011. Impact of interventions on discrete outcomes: Maximum likelihood estimation of the binary choice models with binary endogenous regressors. The Stata Journal 11 (3): 368-385. 
Makate, C, Wang, R, Makate, M and Mango, N 2016. Crop diversification and livelihoods of smallholder farmers in Zimbabwe: Adaptive management for environmental change. SpringerPlus 5 (1135).

Makoka, D. 2012. Status and potential of legumes in Malawi. Lilongwe, Malawi: African Institute of Corporate Citizenship.

Malawi-Government 2011. Malawi Growth and Development Strategy II: 2011 -2016. Lilongwe, Malawi: Ministry of Finance and Development Planning.

Malawi-Government 2016. National Agricultural Policy. Lilongwe, Malawi: Ministry of Agriuculture, Irrigation and Water Development.

Malawi-Government 2018. 2018 Population and Housing Census: Preliminary Report. Zomba, Malawi: National Statistics Office

Minde, I, Madzonga, O, Kantithi, G, Phiri, K and Pedzisa, T. 2008. Constraints, challenges, and opportunities in groundnut production and marketing in Malawi. Bulawayo, Zimbabwe: International Crops Research Institute for The Semi-Arid Tropics (ICRISAT).

Mirie, T and Zemedu, L 2018. Determinants of market participation and intensity of marketed surplus among teff producers in Dera district of South Gondar Zone, Ethiopia. Journal of Development and Agricultural Economics 10 (10): 359-366.

Mmbando, FE, Wale, EZ and Baiyegunhi, LJ 2015. Determinants of smallholder farmers' participation in maize and pigeonpea markets in Tanzania. Agrekon 54 (1): 96-119.

Msere, HW, Tsusaka, TW, Okori, P, Twanje, G, Botha, R and Ndolo, P. 2015. Groundnut production, consumption, and trade in Malawi. Lilongwe, Malawi: International Crops Research Institute for the Semi-arid Tropics (ICRISAT).

Mwangi, M and Kariuki, S 2015. Factors determining adoption of new agricultural technology by smallholder farmers in developing countries. Journal of Economics and Sustainable Development 6 (5).

Omiti, J, Otieno, D, Nyanamba, T and McCullough, E 2009. Factors influencing the intensity of market participation by smallholder farmers: A case study of rural and peri-urban areas of Kenya. African Journal of Agricultural Research 3 (1).

Patnaik, U 1975. Contribution to the output and marketable surplus of agricultural products by cultivating groups in India, 1960-61. Economic and Political Weekly 10 (52 ): A90-A100. 
Pingali, PL 1997. From subsistence to commercial production systems: The transformation of Asian agriculture. American Journal of Agricultural Economics 79 (2): 628-634.

Pingali, PL and Rosegrant, MW 1995. Agricultural commercialization and diversification: processes and policies. Food Policy 20 (3): 171-185.

Pokhrel, DM and Thapa, GB 2007. Are marketing intermediaries exploiting mountain farmers in Nepal? A study based on market price, marketing margin and income distribution analyses. Agricultural Systems 94: 151-164.

Ralitza, D, Katharina, M and Anke, W. Ganyu labour in Malawi: Understanding rural households' labour supply strategies. German Development Economics Conference, , 2010 Hannover 2010, No. 29, Verein für Socialpolitik, Ausschuss für Entwicklungsländer, Göttingen.

Roodman, D 2009. Estimating Fully Observed Recursive Mixed-Process Models with CMP. Working Paper Number 168. Washington, D.C., USA: Center for Global Development

Siambi, M, Okori, P, Sichali, F, Madzonga, O and Audi, P. 2015. Making seed of improved groundnut varieties more accessible to smallholder farmers: lessons and alternative approaches in Malawi. Nairobi, Kenya: International Crops Research Institute for the Semi-Arid Tropics (ICRISAT).

Simtowe, F, Shiferaw, B, Abate, T, Kassie, M, Monyo, E, Madzonga, O, Silim, S and Muricho, G 2010. Assessment of the current situation and future outlooks for the groundnut sub-sector in Malawi. Nairobi, Kenya: International Crops Research Institute for the Semi-Arid Tropics (ICRISAT)

Strasberg, PJ, Jayne, TS, Yamano, T, Nyoro, JK, Karanja, DD and Strauss, J 1999. Effects of agricultural commercialization on food crop input use and productivity in Kenya. Food Security International Development Working Papers. Michigan State University, USA: Department of Agricultural, Food, and Resource Economics.

Tsusaka, TW, Msere, HW, Siambi, M, Mazvimavi, K and Okori, P 2016a. Evolution and impacts of groundnut research and development in Malawi: An ex-post analysis. African Journal of Agricultural Research 11 (3): 139-158.

Tsusaka, TW, Orr, A, Msere, HW, KeeTui, SH, Maimisa, P, Twanje, GH and Botha, R. 2016 b. Do commercialization and mechanization of a "women's crop" disempower women farmers? evidence from Zambia and Malawi. Paper presented at the Agricultural \& Applied Economics Association, Boston, MA, USA, 
648 Wale, E and Chianu, JN 2015. Farmers' Demand for extra yield from improved tef [(Eragrostis tef 649 (Zucc.) Trotter] varieties in Ethiopia: Implications for crop improvement and agricultural

650

651

652

653

654

655

656

657

658

659

660

661

662

663

664

665

666

667 extension. Journal of Agricultural Science and Technology 17: 1449-1462.

Wale, E and Holm-Mueller, K 2017. Explaining the Ethiopian farmers' perceptions on potential loss of traditional crop varieties: a principal components regression analysis. The Journal of Developing Areas 51 (4): 377-395.

Wambua, JM, Ngigi, M and Muhammad, L 2019. Assessment of Differences in Small Farmer Uses of Produce and Determinants of Marketed Surplus of Green Grams and Pigeon Peas in Semi-arid Machakos County, Kenya. East African Agricultural and Forestry Journal 83 (3): 163-175.

Whiteside, M 2000. Ganyu Labour in Malawi and its implications for Livelihood Security Interventions: an analysis of recent literature and implications for poverty alleviation. Agricultural Research \& Extension Network. London, UK: Overseas Development Institute

Wooldridge, JM 2010. Econometric Analysis of Cross Section and Panel Data. London: MIT Press.

Zanello, G 2012. Mobile phones and radios: Effects on transactions costs and market participation for households in northern Ghana. Journal of Agricultural Economics 63 (3): 694-714. 